\title{
El Nino-Southern Oscillation Influences on Food Security
}

\author{
Olivia Muza ${ }^{1}$ \\ ${ }^{1}$ Consultant Economist, Harare, Zimbabwe \\ Correspondence: Olivia Muza, Consultant Economist, Harare, Zimbabwe. E-mail: oliviamuza@gmail.com
}

Received: November 1, 2016

Accepted: July 5, $2017 \quad$ Online Published: September 29, 2017

doi:10.5539/jsd.v10n5p268

URL: https://doi.org/10.5539/jsd.v10n5p268

\begin{abstract}
El-Nino Southern Oscillation (ENSO) is the most recurrent change in climate impacting agriculture productivity and food security. This study investigates ENSO impacts on four cereal crops (maize, millet, sorghum and wheat) using crop production and climate datasets spanning the years 1960-2015. The results of this study reveal that during El Nino (La Nina) maize, sorghum and wheat production decreases (increases) while that of millet increases (decreases). Even though, the correlation is statistically significant for maize only, the outcome is a call to review the macro-food policy taking into account ENSO-related phase effects to redress food insecurity. The study recommends incentives for agricultural productivity including irrigation intensification and small grain value chain development, trade and food security arrangements, income generation opportunities and strategic partnerships for improved food and nutrition security.
\end{abstract}

Keywords: macro food policy, resource economics, vulnerability, Zimbabwe

\section{Introduction}

The food price spikes of the years just prior to 2010 and the economic, political, and social dislocations they generated led to renewed interest on the macroeconomic policy and agriculture link for developing countries (Note 1) (Diaz-Bonilla, 2015; Alamgir and Arora, 2009). Mainly because, agriculture is a key economic sector with large percentages of overall domestic production, exports and employment. It is also the sector with important growth and employment multipliers for the rest of the economy and larger positive effects in reducing poverty than growth in other sectors. There is also a large presence of developing countries in world agricultural production and increasing participation in international trade of those products.

Countries that have successfully reduced poverty and hunger are typically those with high investment rates per agricultural worker (Note 2) (FAO, 2011; Timmer, 2010; Timmer, 2005). For instance, economic growth is important for increased public consumption, public service delivery, employment creation, poverty reduction and thus food secure households are able to save and invest. However, only food security at the macro level provides the appropriate facilitative environment for households to ensure their own food security. A coherently designed macro food policy couples a strategy for food security with a strategy for growth that reaches the poor. Such a macro food policy has three components that, in turn, reinforce the country's food security: rapid growth in the macro economy, poverty reduction through rural economic growth, and stability of the food system. Agriculture and a dynamic rural economy are the keys to integrating the three components. Establishing this link to food security from the macro side allows a country to capture growth opportunities, some quite subtle, that are missed otherwise. Raising agricultural productivity is therefore a key strategy for lifting rural households' income, reducing poverty, ending hunger and achieving food security.

While food security considers the dimensions of availability, access, use and stability of nutritious food, climate variability directly influences the dimension of yield-production and subsequent availability. This paper considers food security at that dimension. Actually, production sets the stage for availability, access, use and stability. Moreover, ENSO is the most recurrent change in climate (Hidore, 2010; Unganai, 1996) and because food security is an ENSO sensitive sector, regular monitoring of the quality of seasons and food production is a priority (Note 3). ENSO data and also ENSO forecasts whose precision is quite reliable for periods up to six months are now recognised as an important tool for assessing food security in various parts of the world (Pfaff, Broad \& Glantz., 1999). Evidence across Southern Africa for instance, shows phase shifts in ENSO accompanied by rainfall anomalies (Ropelewski and Halpert, 1987; Matarira, 1990; Cane, Gidon and Buckland, 1994). Clear signs of climatic variability associated with ENSO phenomenon producing rainfall anomalies are evident 
(Ropelewski and Halpert, 1987; 1989). In Zimbabwe, a correlation exists between maize yield and rainfall (Cane et al., 1994). Maize being the staple crop, the implication of this finding is that food and nutrition security of the population highly correlates with rainfall. However, cereal crops in general contribute to food security of populations and livestock. Total cereal production was 998450 in 2013 produced under 378745 hectares of land (World Bank, 2013). The dietary contribution of cereals is $56 \%$ (FAO, 2011).

As yet, there is insufficient research of the ENSO phase effect of El Niño (warming effect) and La Niña (cooling effect) on cereal production variability. The aim of the paper is to investigate how the warming and cooling effects of ENSO impact sorghum and millet (dry land crops), maize (corn) and wheat (both dry land and irrigated crops). Study is timely, as reduced irrigation capacity is expected to worsen food insecurity in Zimbabwe, of the 220000 hectares of installed irrigation only 153000 hectares of land is under functional irrigation. While the primary aim of the paper is to add quantitative estimates of agricultural variability to climate literature it also provides policy makers and food-policy analysis in Zimbabwe with strong evidence of the ENSO phase effects on cereal production. The paper begins with a global discussion of the ENSO phenomenon and its influence on climate variability followed by an analysis of the macro-economic and food security link and illustrations of vulnerability (economies, regions, ecosystems, and populations). Time series correlations of climatic and production data (1960-2015) are illustrated and paper concludes with a discussion of policy implications.

\section{Theoretical Review}

\subsection{ENSO}

ENSO events are a strong determinant of interannual climate variability in many countries in Africa, Asia and in North and South America. For example, during an El Niño, associated climate anomalies called 'teleconnections' are felt beyond the pacific region including regional land and sea surface warming, changes in storm attacks and changes in precipitation patterns (Kovats, 1999). El Niño is also a local warming of surface waters that takes place in the entire equatorial zone of the central and eastern Pacific Ocean of the Peruvian coast and which affects the atmospheric circulation worldwide (Kiladis and Diaz, 1989). It is a recurrent weather phenomenon that takes place approximately every two to seven years and usually last between 12 and 18 months. It usually peaks around Christmas, hence the name of the phenomenon: El Niño is Spanish for Christ Child-'a little boy'. La Niña refers to the cold equivalent of El Niño-the girl child.

An El Niño event is defined by a high Oceanic Niño Index (ONI), which is based on Sea Surface Temperature (SST) departures from average in the region in the central equatorial Pacific. The Southern Oscillation is an East-West balancing movement of air masses between the Pacific and the Indo-Australian areas. It is associated (roughly synchronised) with typical wind patterns and El Niño, and measured by the Southern Oscillation Index (SOI) (Parker, 1983). It emerges, El Niño is the oceanic component, while the Southern Oscillation is the atmospheric one. This combination gives rise to the term ENSO. Although there is no perfect correlation between El Niño and the Southern Oscillation as regards minor variations, large negative values of the SOI are associated with warm events. However, historical record of the SOI reveals several important features:

- Although ENSO events occurred on average about every four years from 1935-1995 and in that sense are quasi-periodic, their occurrence is highly irregular. For example, from 1978-1986 there was only one ENSO event, but from 1990-1995 there was either one prolonged event or several that followed each other in close succession

- Some ENSO events are intense, while others are not. The 1997/1998 ENSO was perhaps the fiercest in the past 100 years, and the 1982 event was also unusually intense. Others, however, are barely noticeable

- ENSO states alternate with "normal states" or La Niña events

La Niña and El Niño events can simply be viewed as alternating states of ocean-wind circulation patterns, with neither one nor the other being abnormal. During ENSO-Neutral phases, atmospheric patterns are controlled more by other climate drivers. Needless to say, what ultimately causes ENSO has engendered and continues to engender debate; it also raises the question of what will happen to ENSO as climate warms (Note 4) (Mathez, 2009). In Zimbabwe, the probability of El Niño occurrence is $47 \%$ and that of La Niña is $49 \%$ (Shoko and Shoko, 2014). Additionally, the probability of the occurrence of La Niña induced wet years is $30 \%$ while the probability of the occurrence of El Niño induced drought is $34 \%$. A number of studies, have confirmed a correlation between ENSO and annual rainfall patterns (Rasmussen and Carpenter, 1982; Ogallo, 1988; Chifurira and Chikobvu, 2010; Makarau and Jury, 1997; Cane et al., 1994). 


\subsection{Food Security in a Macro-Economic Context}

The macro-economy plays a major role in determining food security at all levels, particularly at the household level through its impact on production (the effect of incentives), availability (the effect of trade and food security arrangements) and access (the effect of the capacity to impact through exports and capital flow and the effect of employment and income generation) (Mohiuddin and Poonam, 1991). It also extends to the priority accorded to agriculture and food in government planning and the budgetary allocation for public investment including the monetary and fiscal policies as reflected in the country's inflationary status and the government's deficit or surplus status. ENSO - via its effects on cereal production, yield and agriculture value added - explains the fact that wealth and growth are systematically lower in the tropics (Hsiang and Meng, 2015). According to Naylor (2002), climate patterns associated with El Niño and La Niña episodes exert dominant influences on agricultural production and food security. Studies have shown the importance of ENSO to global production (Lizumi et al., 2014) and global agricultural production areas (FAO, 2014). In Zimbabwe, Cane et al. (1994) found that maize yield is a reflection of rainfall.

Climate variability caused by ENSO is expected to reduce food production particularly in regions where yields are already low. These changes engender particular concern because of their direct and potentially severe impacts on agriculture, water supplies and ecosystems (Mathez, 2009). Climate variability affects food availability via its impact on yield-production and subsequent availability is reduced. For example, reduced yields of rice, maize and wheat, key to many African diets and export markets are anticipated even if temperature increases very slightly by $1-2 \%$ (Pedercini, Kanamaru \& Derwisch, 2012). Given that farmers are rational beings who make economic decisions to maximise productivity, price is a major determinant in agriculture (FAO, 2011). For instance, farmers are unlikely to invest in measures to raise productivity when price changes are unpredictable. Hence, famers need to know the prices their crops are going to fetch at harvest time, months away. If prices are high they plant more. If low prices are forecast they plant less and cut costs. Therefore, increased investment in agriculture boosts local production and is one response to high food prices.

Although climate change is not only one of the variables affecting food price volatility, it appears to be an important one. According to one model, temperature increases of more than 3 degrees Celsius could increase prices by $40 \%$ (Easterling et al., 2007). The level of individuals, people living on less than US1.25 a day may need to skip a meal when food prices rise. In 2010, the world's Low Income Deficit Countries (LIFDC) spent a record US $\$ 164$ billion on food imports, representing a rise of $20 \%$ on the year before (FAO, 2011). According to the World Bank between 2010-2011 rising food costs pushed nearly 70 million people into extreme poverty. FAO's food price index confirmed that prices of major food commodities were creeping closer to the high reported in June 2008 citing adverse weather conditions as one of the primary drivers of wheat production shortfalls experienced earlier that same year.

Climate variability also causes food supply shortages as countries with weak purchasing power tend to import as little as possible from global markets, suffering consumption deficits during times of high prices or production declines (Funk and Brown, 2009). In addition, climate variability threatens household income generation capacity. By reducing real income, rising prices can worsen the prevalence of hunger and malnutrition through lowering the quantity and quality of food consumed (FAO, 2011). In this sense, climate variability is a hunger risk multiplier for example in 2010, 1.7 million people in Zimbabwe were affected by natural disasters- a protracted crisis mode resulting in food aid amounting to 0.1 million tonnes of grain equivalent in 2010 (FAO, 2011). Concerns of large scale short-term relief have been recorded in view of the fact that it is ineffective in overcoming the structural reasons for food insecurity and might even lower incentives to invest in agriculture and domestic food production (FAO, 2011; Ward et al., 2013).

\subsection{Vulnerable Economies, Vulnerable Regions, Vulnerable Ecosystems and Vulnerable Populations}

Assessing the vulnerability of different geographic areas, countries, social groupings and individuals identifies those who will be most adversely affected, which information can be used to guide policy and interventions to assist production. Developing countries in the tropical regions are usually assumed to have lower adaptive capacities than countries with high levels of economic and human development. This is because of lower availability of resources and institutions necessary to facilitate adaption (Parry, 2007). Worldwide, rates of persons affected by drought/famine account for about half of all disaster victims and these show a significant association between ENSO cycles (Kovats, 1999). Reduced capacity of poor populations to adapt to existing threats and alteration of long-established weather effects lead to vulnerability.

Food production is most susceptible to drought in arid regions where precipitation pattern is markedly seasonal, or is otherwise highly variable (Kovats, 1999). El Nino is important because it is associated with drought in 
many vulnerable regions at the same time. This aggregate effect has even led to several world food crises (Dyson, 1996). Regions most likely to be adversely affected by climate vulnerability are those already vulnerable to food insecurity and malnutrition namely Sub-Saharan Africa and Asia (Thompson, Cohen \& Meerman., 2012; Tirado \& Meerman., 2012). It is within these regions that the IPCC estimates the largest number of people will be affected (Nicholls et al., 2007).

Substantial amounts of agricultural land have already been compromised or lost due to desertification, soil salination and other climate change related trends in both areas (Thompson et al., 2012). Approximately 20-30\% of plant and animal species assessed so far are believed to be at risk of extinction should increases in global average temperature exceed 1.5-2.5 degrees Celsius (Fischlin et al., 2007). In addition to global warming per se, a number of related risks currently threaten climate change, namely increased flooding and drought, and associated disturbances such as wildfires and insect plagues. Many of these events are now occurring in close proximity to each other, creating situations that are unprecedented in terms of the number of hazards threatening a single ecosystem within given, often short time period. When combined with pollution and overexploitation of resources, vulnerability increases (Fischlin et al., 2007).

Most vulnerable groups are those reliant on natural resources for food and livelihoods (Easterling et al., 2007; Mendelson and Zilberman, 2009) in reference point smallholder farmers, pastoralists, traditional societies, indigenous people and coastal populations. These populations have extremely low income and adaptive capacity, are politically marginalised, are risk averse, may have little or no social protection programmes or healthcare, and they are concentrated in those areas most exposed to climate change (Thompson et al., 2012). The rural poor tend to live and work in ecologically fragile, economically marginal and environmentally degraded areas (Mendelson and Zilberman, 2009). Many of the world's poorest and most vulnerable groups are women living in rural areas in developing countries who are wholly dependent on subsistence agriculture to feed their families (Thompson et al., 2012).

Rural women, female smallholders in particular, may be disadvantaged in terms of access to key productive assets for farming and services such as land, water, rural infrastructure, technology and information, credit and extension services (Brody, Zahran, Vedlitz \& Grover., 2008). These women therefore tend to have limited adaptive capacities, and are highly dependent on climate sensitive resources such as local water and food supplies (Smith et al., 2009). Climate change is expected to exacerbate these gender inequalities with women being disproportionately affected by depletion of natural resources and reduced agriculture production (Parikh and Denton, 2002). Women are differentially at risk from many elements of weather related hazards including for example, the burden of work in recovery of home and livelihood after a catastrophic event (Daw, Adger, Brown, \& Badjeck., 2009). It is also assumed for many societies that women possess lower levels of adaptive capacity to men for example; they have fewer economic options, generally lower educational attainment, a greater lack of rights and access to resources and may be more likely to endure the burden of care after hazards. Women headed households, which tend to be among the poorest in many societies are considered especially vulnerable.

\section{Data and Methods}

\subsection{Index of ENSO}

The ONI for the period 1960-2015 was used to determine whether El Niño or La Niña conditions affected production of the principal four cereal crops. ENSO teleconnections are well captured in the 3-month means anomalies (Lizumi et al., 2014). The strength of ENSO is taken as the average of November-January SST anomalies, which is the period when the ENSO has been found to be strongest on the seasonal summer rainfall (Manatsa and Mukwada, 2012). According to Mason \& Jury (1997) the influence of ENSO events is strongest during the peak austral summer rainfall months of December-March because that is when the warm and cold events have reached maturity and when the upper westerlies have retreated significantly poleward. The ONI was accessed on the website http://ggweather.com/enso/oni.htm

\subsection{Rainfall}

Rainfall data was obtained from the Metrological Services Department of Zimbabwe (MSDZ) for the period 1970-2015. The dry season stretches from April to October- which is also the winter season and its rain free and colder. The wet season stretches from November-March, which is also the summer season.

\subsection{Crop Data}

Crop data was obtained from the United States Department of Agriculture (USDA) website which showed consistent cereal crop data from 1960. Where feasible, data was verified from national studies including the 
Zimbabwe Vulnerability Assessment Committee, (ZimVac) and statistical offices, Zimstat and Central Statistics Office (CSO).

\section{Results and Discussion}

\subsection{Descriptive Statistics}

Between 1950 and 2010, Zimbabwe experienced 21 El Niño events (38\% above normal rainfall and 62\% below normal rainfall), 15 La Niña events (67\% above normal rainfall and 33\% below normal rainfall) and 24 neutral years $(54 \%$ above normal rainfall and $46 \%$ below normal rainfall), Table 1 . This evidence illustrates that not all El Niño years are drought years. Drought occurrences and El Niño do not always have a one to one relationship.

Table 1. ENSO versus Zimbabwe rainfall 1950-2010

\begin{tabular}{llll}
\hline Weather Event & Above Normal & Below Normal & Total \\
\hline El Niño & $8(38 \%)$ & $13(62 \%)$ & 21 \\
La Niña & $10(67 \%)$ & $5(33 \%)$ & 15 \\
Neutral & $13(54 \%)$ & $11(46 \%)$ & 24 \\
& & & 60 \\
\hline
\end{tabular}

Source: (MSDZ, 2016)

El Niño years have a positive ONI while La Niña years illustrate a negative one (Figure 1). El Niño years are illustrated as above, while La Niña years are those below the x-axis. Strong El Niño events were recorded in the years 1957-58; 1965-66 and 1972-73 while very strong ones were recorded in 1982-83; 1997-98 and 2015-16. Strong La Niña events were recorded in the years 1973-74; 1975-76 and 1988-89.

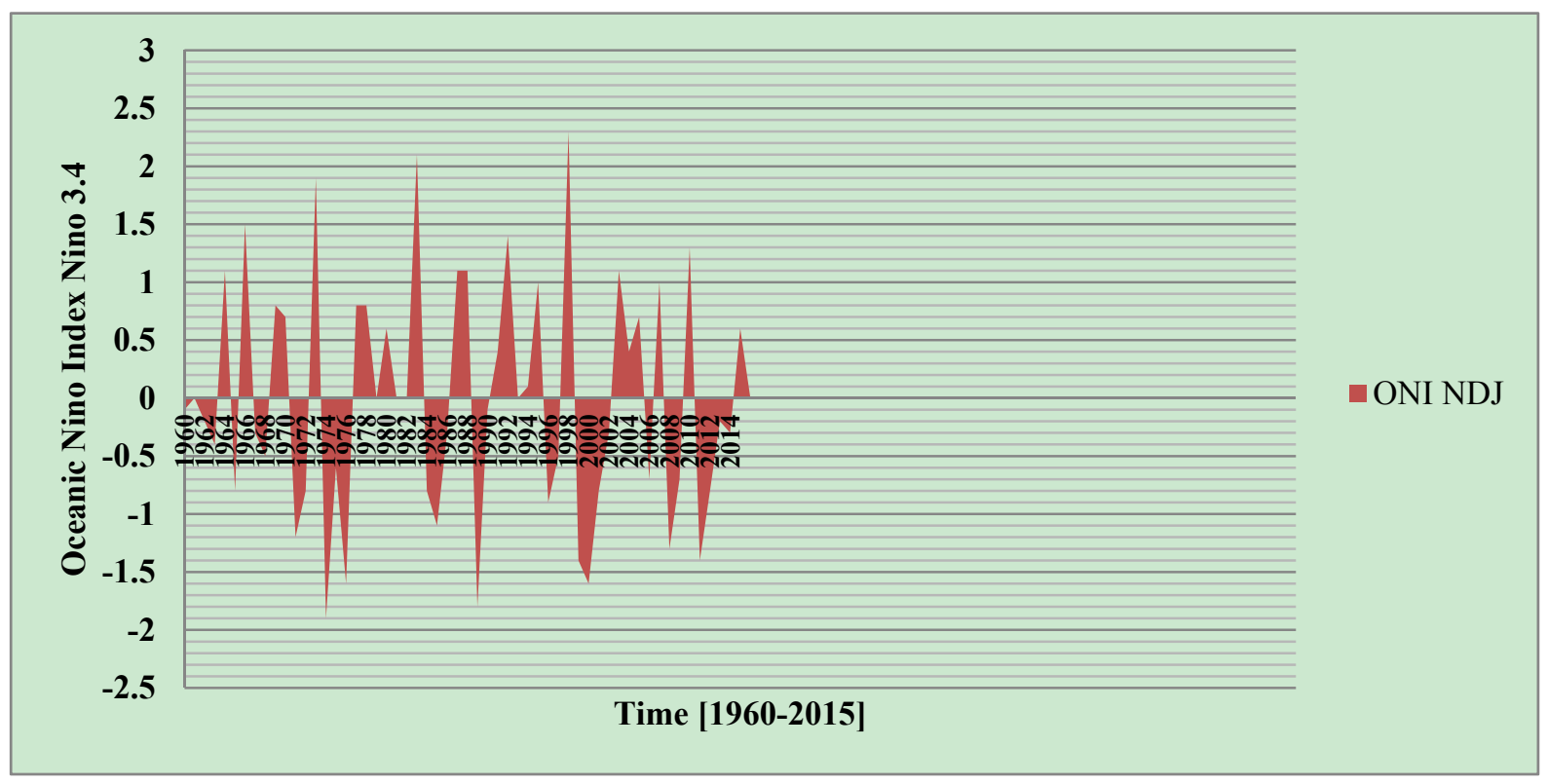

Figure 1. Oceanic Nino Index- NDJ

Maize (14\%) is the third largest contributor after tobacco (25\%) and livestock (24\%) followed with cotton $(12.5 \%)$, beef and fish (10\%), sugar and horticulture (7\%). Maize is an apart cereal crop, in terms of cultivated production at national level such that total cereal production is a reflection of maize production, Figure 2. It is followed by millet, sorghum and wheat respectively. In Zimbabwe, maize is the primary food crop grown by small-holder farmers and is preferred over more drought-resistant crops such as millet and sorghum. 


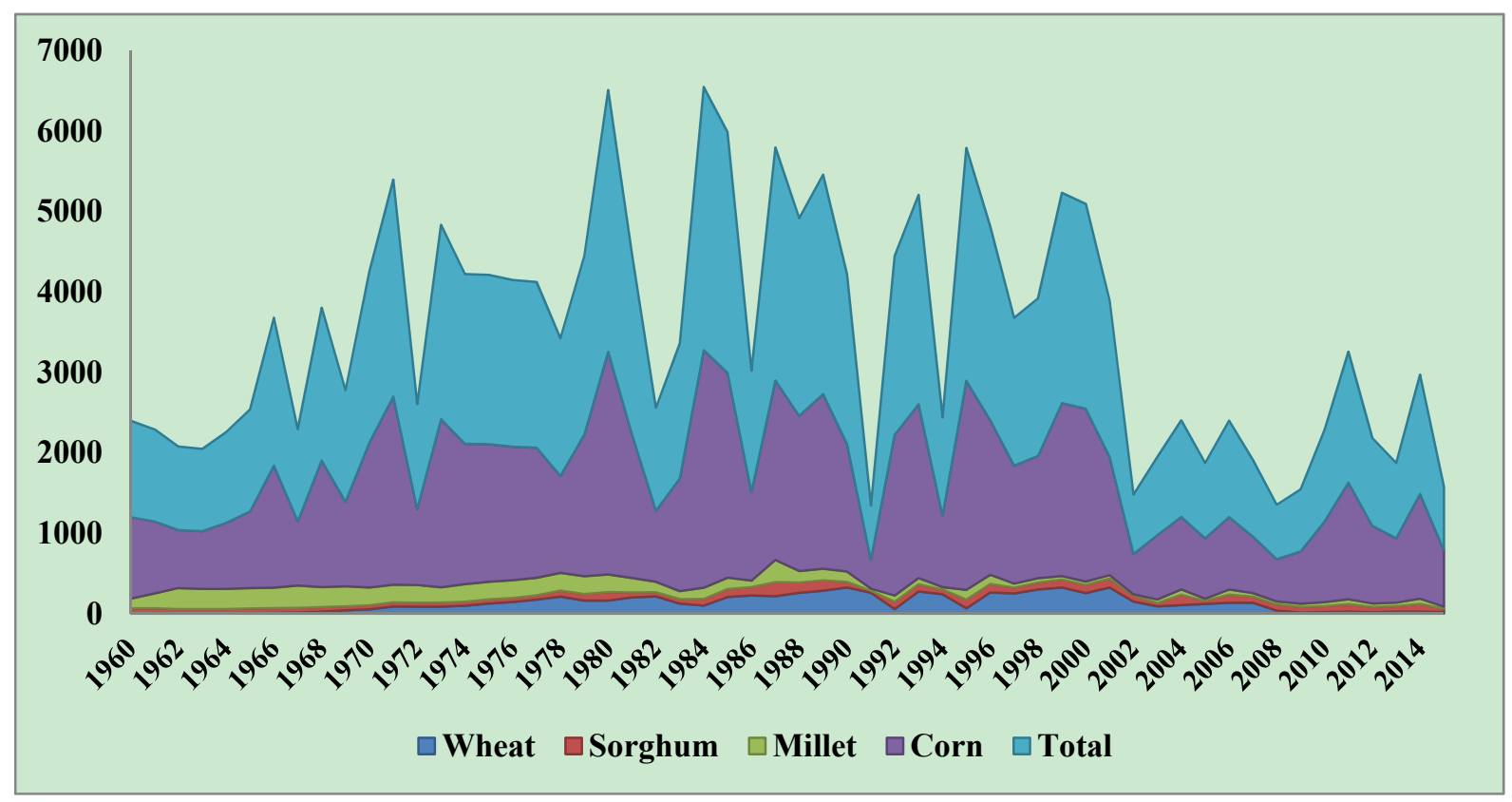

Figure 2. Total Cereal Production for Maize, Millet, Sorghum and Wheat

Maize production pattern is different from millet, sorghum and wheat for the 45 year period (1970-2015). Whenever maize had an ascending trend, millet, sorghum and rapoko illustrated descending trends, Figure 3 and Figure 4.

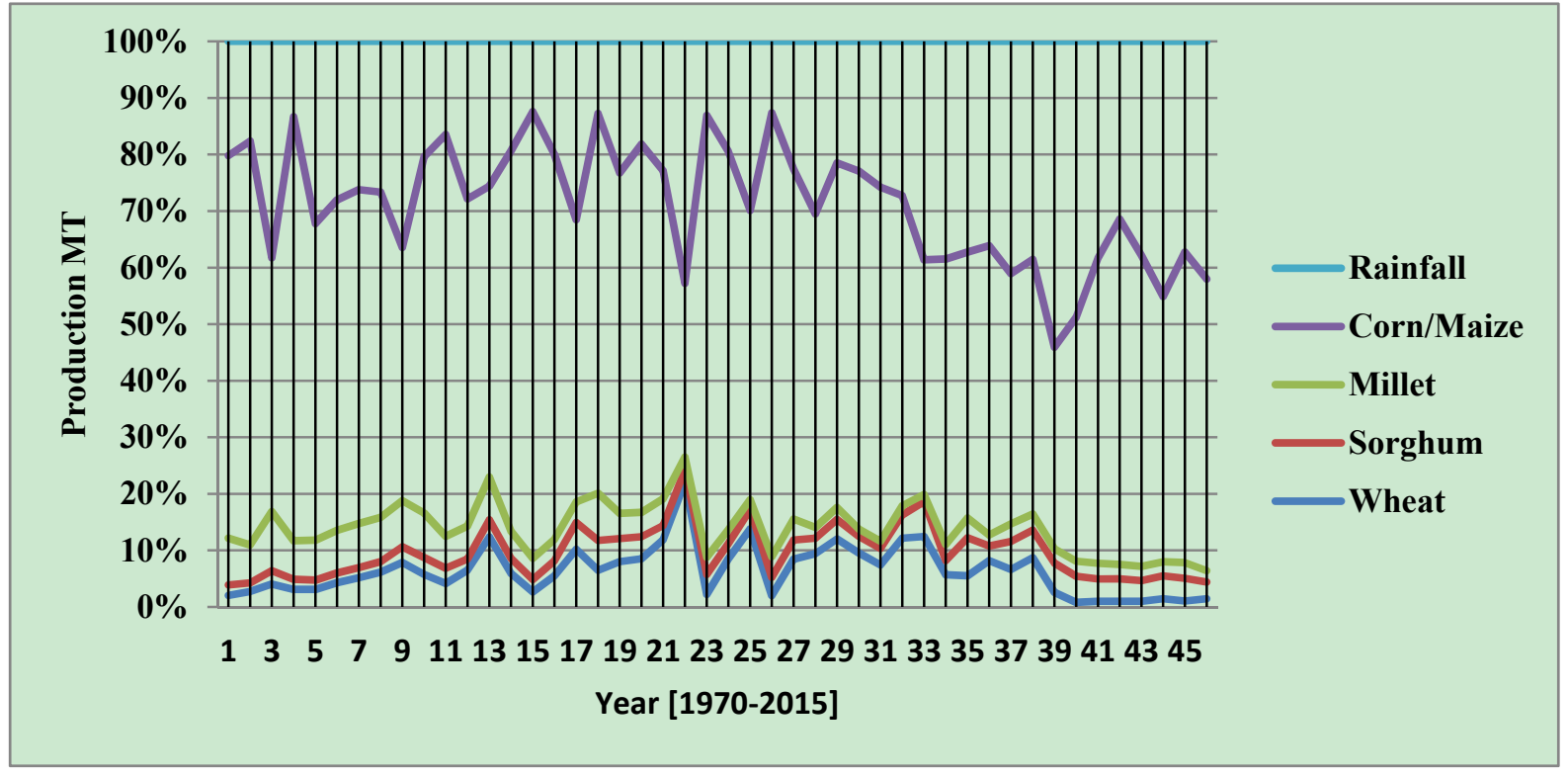

Figure 3. Rainfall versus Maize, Millet, Sorghum and Wheat production patterns 


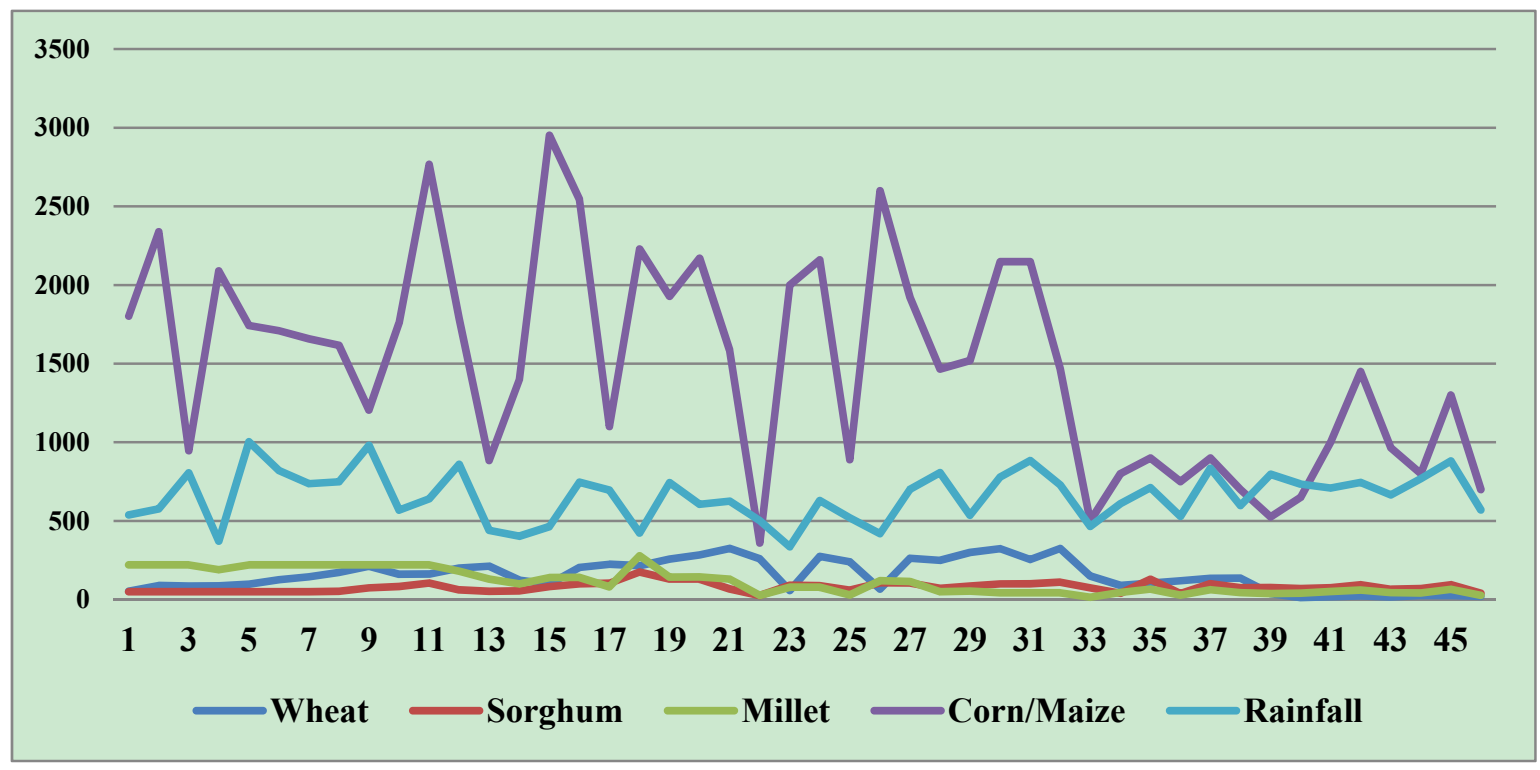

Figure 4. Rainfall versus Maize, Wheat, Millet and Sorghum

\subsection{Correlations between Cereal Production and ENSO}

Correlation evidence between the ONI and cereal production and change in cereal production shows that wheat, maize and sorghum are negatively correlated with the ONI while millet has positive correlation, Table 2 . This means that, during the El Niño phase (La Niña), as the ONI increases (ONI decreases), production of wheat, maize and sorghum decreases (increases) while that of millet increases (decreases). This is an interesting finding as popular belief has always been that all small grain production increases (decreases) during the El Niño (La Niña).

However, our results tend to be similar to those of Lizumi et al. (2014) indicating that El Niño likely reduce the global-mean yields of maize and wheat (by -4.3 to $+0.8 \%$ ). Another global study, reveals that El Niño shocks cause on average a reduction in global production of rice and maize while La Niña episodes, are associated with increased global rice and decreased global wheat and maize production (Abdolrahimi, 2016). In yet another global study, Gutierrez (2017) found that La Niña exerts, on average, a stronger and negative impact on wheat yield anomalies, exports and stock-to-use ratios than El Niño.

Evidence from the Sahel region shows El Niño events as devastating to millet yield with little or no impact on maize and sorghum production, attributable to the lower length of growing period for maize and sorghum compared to millet. On the other hand, La Niña events favor cereal production and mirrored sorghum yield during the La Niña years of 1973-1976 (Okonkwo and Demoz, 2014). Shuai, Zhang, Tao \& Shi. (2016), found that during El Niño years, most areas of China, especially in the north, experience a maize yield increase, whereas some areas in the south have a decrease in yields. During La Niña years, there is an obvious decline in maize yields, mainly in the north and northeast, and a general increase in the south. Evidence from the South Region of Brazil (Rio Grade do Sul) also supports that El Niño is favourable to the non-irrigated spring - summer crops, such as soybean and maize, raising their mean yields whereas, the La Niña phenomenon is responsible for harvest losses of these two main grain - producing crops in the state. On the other hand, the La Niña phenomenon is favourable to the production of wheat and other winter cereals and in several cases is favourable also to irrigated rice (Berlato \& Fontana, 2001). However, the same study found El Niño unfavourable to the spring - summer crops (soybean, maize, rice, for instance) when there is a rainfall above climatological mean in April and May of the second year of the phenomenon (the maturation and harvest time) as occurred during the great El Niño of 1982/1983. In Mexico, El Niño (La Niña) episodes seem to result in an increase (decrease) in wheat yields, which is consistent with previous reports of an increased (decreased) precipitation over northwest Mexico during these events (Zavala \& Cota, 2002). 
Table 2. Correlation between ONI NDJ and cereal production

\begin{tabular}{lrrrr}
\hline & Wheat & Sorghum & Millet & Corn \\
\hline Level & $-8.1 \%$ & $-8.3 \%$ & $3.2 \%$ & $-8.2 \%$ \\
\% Change & $-5.4 \%$ & $8.8 \%$ & $19.6 \%$ & $31.2 \%$ \\
\hline
\end{tabular}

However, regression analysis shows a statistically significant relationship exists between ONI and maize production only, Table 3. The statistically insignificant relationship for wheat, sorghum and millet may be due to other factors, for example, rainfall data which needs to be further investigated. In general, ENSO impact differs by crop according to its water requirement, dominant production conditions (irrigated or rainfed), crop season, applied technology and farmer choice (Yokoyama, 2002).

Table 3. Regression analysis for ONI NDJ and cereal production

\begin{tabular}{lrrrr}
\hline & Intercept & P-value & ONI NDJ & P-value \\
\hline Wheat & 0.224 & 0.036 & -0.040 & 0.696 \\
Sorghum & 0.097 & 0.225 & 0.050 & 0.522 \\
Millet & 0.128 & 0.188 & 0.137 & 0.151 \\
Corn & 0.168 & 0.111 & 0.244 & 0.021 \\
\hline
\end{tabular}

\section{Conclusions}

Macro-food policies to address ENSO-induced shortages have always been built around domestic production, import capacity, existence of food stocks and food aid. However, a well considered drought strategy interfacing La Niña and El Niño phase impacts improves food security planning. In the context of Agenda 2030 for Sustainable Development, in particular Sustainable Development Goal (SDG) 2, national strategies to end hunger, achieve food security and improve nutrition, and promote sustainable agriculture are essential. ENSO-phase responses highlighting production incentives, trade and food security arrangements and income generation approaches are recommended.

\subsection{Production Incentives}

\subsubsection{Irrigation Intensification}

Cereal production intensification under irrigation systems ensures food availability during negative La Niña and El Niño years as farmers are able to produce on and off season. Irrigation is a risk mitigation and adaptation option for ENSO-sensitive sectors and keeps pace with changed seasons and variability (Muza, 2012; Mano and Nhemachena, 2007). In Zimbabwe, irrigation is important because a total of 53000 hectares of land is under non-functional irrigation. Yet, wheat and maize thrive under both rainfed and irrigation conditions. While a macro-food policy has strategies for input supply, agronomic practices adjustment of the planting times, crop varieties and use of water wise techniques, improved crop varieties and other innovations, risk mitigation and resilience are key considerations (Tilman, Balzer, Hill \& Befort., 2011)

\subsubsection{Small Grain Value Chain Development}

While small grain production can complement food security, most people shun its production because of limited market options. Additionally, small grains are regarded as women crops and men are not forthcoming in their production. Another key gap in small grain value chain production is the low domestic demand. Small grain value chain development thus is a key strategy to double agricultural productivity and incomes for vulnerable small holder farmers especially women. Through public-private partnerships (PPPs) opportunities for engaging women farmers are recommended. Need for rapid growth in agricultural productivity, with substantial participation by small farmers where they are a significant part of the production structure, is increasingly recognised by macro policy makers as a key element in the overall development strategy (Timmer, 2010). Yet, the role of small grains in the government initiative, Command Agriculture is silent, focusing instead on maize production only. The macro-food policy could also craft specific interventions targeting women farmers in small grain production. Supporting women farmers improves gender equity as stipulated in SDG 5.

Generally, family consumption is concentrated on wheat and maize. Yet, millet and sorghum are nutritious grains. 
Creative agro-processing ways to enhance small grain consumption and nutritious meals will stimulate local demand. The small grain value chain can be developed to take advantage of the nutritious elements and also exploring fortification options. The National Micronutrient Survey (2012) for instance, notes women and children as deficient of major micronutrients which are necessary for growth and development. The Zimbabwe National Food Fortification Strategy is thus a key step.

\subsection{Trade and Food Security Arrangements}

Building up strategic grain reserves/buffer stocks at the local and national levels is important during ENSO-induced shortages. The Grain Marketing Board (GMB) and the soon to be functional Wheat Marketing Board (WMB) could review strategic reserves in view of the regularity with which El Niño comes and climate variability and change in general. At the local level, Zunde Ramambo for instance, is a key traditional social protection mechanism that has been used to safeguard vulnerable groups like orphans, elderly, disabled and widowed groups. Revival of this social safety net reduces vulnerability during ENSO-related shocks, climate change and variability.

Food security does not depend on production strategies alone, hence in the case of severe or prolonged ENSO-related shortages, the import capacity of the country needs to be guaranteed through ENSO informed forecasts. An additional budget can be called for and should be readily available to ensure adequate import capacity of grains. This also goes with measures to ease prices for instance price monitoring to ensure vulnerable populations are able to access food. Farmers as rational beings respond to higher grain prices by increasing output and reaping higher incomes and while it's not always possible to increase grain prices, possible interventions focusing on reducing the cost of production can stimulate production. Increased production and government investment insulates consumers from global price instability and their negative transmission to domestic markets.

\subsection{Income Generation, Savings and Investment}

The government through the relevant government ministries should also promote fair pricing for cereals in both domestic and international markets to encourage farmers to produce more, at the same time enable farmers to save and invest and enable consumption smoothing during negative La Niña and El Niño years. This includes designing innovative financial products to cushion farmers during ENSO-related shocks. For instance, community based financial products including Village Savings and Lending Schemes (VSALs), insurance schemes and microfinance all encourage farmers to save and thus are able to invest during bumper years and cushion themselves during negative years.

\subsection{Strategic Partnerships}

Building strategic partnerships as stated in SDG 17, is an important macro-food strategy to ensure early warning information regarding cereal/grain production is decentralised to local level actors. MSDZ (early warning information) and the Ministry of Agriculture, Irrigation and Mechanisation (crop production), Media Houses (information dissemination), Ministry of Finance (fiscal policy and public investment allocations), Central Bank (exchange rates and money supplies), heads of key planning agencies and all government and non-government actors (strategic approaches and sectoral allocations), could craft tripartite agreements that facilitate more precise agricultural planning, decision making and implementation for ENSO induced changes, climate change and variability in general. Specific crop combinations for specific vulnerable regions, ecosystems and populations could be developed and shared with key local agriculture extension officers, farmer field schools, and local groups. This will also facilitative local based monitoring and enforcement disaster risk plans.

\section{Acknowledgements}

I acknowledge the United States Department of Agriculture (USDA) for convening a very insightful Seminar on Methodology for Agricultural Censuses and Surveys, in Rome, Italy from the $24^{\text {th }}-25^{\text {th }}$ of October 2016. I am greatly indebted to all the facilitators and the young statisticians that were present and to Michael Steiner for assistance with the workshop and publication. Support from the MSDZ, in particular, the contribution of information by Dr. A. Makarau, Linia Mashawi and Shingirai Nangombe is highly acknowledged. I am very grateful to Dr.C.A.Yoonus for the guidance. I am very thankful to all who contributed to this work directly and indirectly.

\section{References}

Abdolrahimi, M. (2016). The effect of El Niño Southern Oscillation (ENSO) on world cereal production. The University of Sydney. Retrieved from http://hdl.handle.net/2123/15498 
Alamgir, M., \& Arora, P. (1991). Providing food security for all. IFAD studies in rural poverty (USA). Retrieved from http://library.wur.nl/WebQuery/titel/594586

Berlato, M. A. \& Fontana, D. C. (2001). Impacts of El Niño and La Niña on agricultural production in Southern Brazil and use of climate forecasts in agriculture. In Cunha, G. R., Hass, J. C., \& Berlato, M. A. (Eds.), Applications of climate forecasting for better decision-making processes in agriculture (pp. 217-241). Passo Fundo, Embrapa Trigo. Brazil and the use of climate forecasts in agriculture. Applications of climate forecasting for better decision-making processes in agriculture. Passo Fundo, Embrapa Trigo.

Brody, S. D., Zahran, S., Vedlitz, A., \& Grover, H. (2008). Examining the relationship between physical vulnerability and public perceptions of global climate change in the United States. Environment and behavior, 40(1), 72-95. https://doi.org/10.1177/0013916506298800

Cane, M. A., Eshel, G., \& Buckland, R. W. (1994). Forecasting Zimbabwean maize yield using eastern equatorial Pacific sea-surface temperature. Nature, 370.6486, 204-205.

Chifurira, R., \& Chikobvu, D. (2010). Predicting rainfall and drought using the Southern Oscillation Index in drought prone Zimbabwe.

Daw, T., Adger, W. N., Brown, K., \& Badjeck, M. C. (2009). Climate change and capture fisheries: potential impacts, adaptation and mitigation. Climate change implications for fisheries and aquaculture: overview of current scientific knowledge. FAO Fisheries and Aquaculture Technical Paper, 530, 107-150. Retrieved from http://www.fao.org/fileadmin/user_upload/newsroom/docs/FTP530.pdf\#page=113

Díaz-Bonilla, E. (2015). Macroeconomics, agriculture, and food security: A guide to policy analysis in developing countries. IFPRI.

Dyson, T. (1996). Population and food: global trends and future prospects. Routledge, London.

Easterling, W., Aggarwal, P., Batima, P., Brander, K., Erda, L., Howden, S., ... Tubiello, F. (2007). Food, fibre and forest products. In M. L. Parry, O. F. Canziani, J. P. Palutikof, P. J. van der Linden, \& C. E. Hanson (Eds.), Climate change 2007: impacts, adaptation and vulnerability (pp. 273-313). Contribution of Working Group II to the Fourth Assessment Report of the Intergovernmental Panel on Climate Change. Cambridge University Press, Cambridge, UK.

FAO (GIEWS). 2014 El Niño-Southern Oscillation (ENSO): Review of possible impact on agricultural production in 2014/15 following the increased probability of occurrence. GIEWS Up date, 17 June 2014. Retrieved from http://www.fao.org/giews/english/shortnews/enso17062014.pdf

FAO, I., IMF, O., \& UNCTAD, W. (2011). the World Bank, the WTO, IFPRI and the UN HLTF (2011). Price Volatility in Food and Agricultural Markets: Policy Responses. Rome, FAO. Retrieved from http://g20india.gov.in/hindi/pdfs/2011-B-June-Joint-Report-on-Food-Price.pdf

Fischlin, A., Midgley, G. F., Price, J. T., Leemans, R., Gopal, B., Turley, C., ...Velichko, A. A. (2007). Ecosystems, their properties, goods, and services. Climate Change 2007: Impacts, Adaptation and Vulnerability. In M. L. Parry, O. F. Canziani, J. P. Palutikof, P. J. van der Linden, \& C. E. Hanson (Eds.), Contribution of Working Group II to the Fourth Assessment Report of the Intergovernmental Panel on Climate Change (pp. 211-272). Cambridge University Press, Cambridge.

Funk, C., \& Brown, M. E. (2009). Declining global per capita agricultural production and warming oceans threaten food security. Food Security, 1(3), 271-289.

Gutierrez, L. (2017). Impacts of El Niño-Southern Oscillation on the wheat market: A global dynamic analysis. PloS one, 12(6), e0179086. https://doi.org/10.1371/journal.pone.0179086

Hidore, J. J., Oliver, J. E., Snow, M., \& Snow, J. (2009). Climatology: An Atmospheric Science (3rd ed.). Hardcover.

Hsiang, S. M., \& Meng, K. C. (2015). Tropical Economics. American Economic Review, 105(5), 257-61.

Hsiang, S. M., \& Meng, K. C. (2015). Tropical economics. The American Economic Review, 105(5), 257-261.

Hulme, M. (1992). Rainfall changes in Africa: 1931-1960 to 1961-1990.International Journal of Climatology, 12(7), 685-699.

Kiladis, G. N., \& Diaz, H. F. (1989). Global climate anomalies associated with extremes in the Southern Oscillation. $\quad J . \quad$ Clim., $2, ~ 1069-1090$. https://doi.org/10.1175/1520-0442(1989)002\%3C1069:GCAAWE\%3E2.0.CO;2

Kovats, R. S., Ebi, K., \& Menne, B. (2003). Health and Global Environmental Change. Vol. 1: Methods of 
Assessing Human Health Vulnerability and Public Health Adaptation to Climate Change. Copenhagen:World Health Organization, Health Canada, United Nations Environmental Programme, World Meteorological Organization. Retrieved from http://researchonline.lshtm.ac.uk/id/eprint/14942

Lizumi,T., Luo, J., Challinor A., Sakurai, G., Yokozawa, M., Sakuma, H., Brown, M., \& Yamagata, T. (2014). Impacts of El Niño southern oscillation on the global yields of major crops. Nature Communi., 5, 3712.

Makarau, A., \& Jury, M. R. (1997). Predictability of Zimbabwe summer rainfall. International Journal of Climatology, 17(13), 1421-1432.

Manatsa, D., \& Mukwada, G. (2012). Rainfall mechanisms for the dominant rainfall mode over Zimbabwe relative to ENSO and/or IODZM. The Scientific World Journal, 2012. http://dx.doi.org/10.1100/2012/926310

Mano, R., \& Nhemachena, C. (2007). Assessment of the economic impacts of climate change on agriculture in Zimbabwe: A Ricardian approach. (CEEPA Discussion Paper N0.11) University of Pretoria. South Africa. Retrieved from https://ssrn.com/abstract=1004406

Mason, S. J., \& Jury, M. R. (1997). Climatic variability and change over southern Africa: a reflection on underlying processes. Progress in Physical Geography, 21(1), 23-50. https://doi.org/10.1177/030913339702100103

Matarira, C. H. (1990). Drought over Zimbabwe in a regional and global context. International Journal of Climatology, 10(6), 609-625.

Mathez, E. A. (2009). Climate change: The science of global warming and our energy future. New York: Columbia University Press.

Mendelsohn, R. O., \& Dinar, A. (2009). Climate change and agriculture: an economic analysis of global impacts, adaptation and distributional effects. Edward Elgar Publishing.

Mohiuddin, A., \& Poonam, A. (1991). Providing Food Security for all.Publishers, Intermediate Technology Publications, 103, 105.

Muza, O. (2012). Rural Impact Assessment of Agriculture Water Systems in a Climate Change Context. Journal of Agricultural Science and Technology, 1373-1385.

Naylor, R., Falcon, W., Wada, N., \& Rochberg, D. (2002). Using El Niño-Southern Oscillation climate data to improve food policy planning in Indonesia. Bulletin of Indonesian Economic Studies, 38(1), 75-91. http://dx.doi.org/10.1080/000749102753620293

Nicholls, R. J. et al. (2007). In Parry, M. L., Canziani, O. F., Palutikof, J. P., van der Linden, P. J., \& Hanson, C. E. (Eds.), IPCC Climate Change 2007: Impacts, Adaptation and Vulnerability (pp. 315-356). Cambridge Univ. Press.

Ogallo, L. J. (1988). Relationships between seasonal rainfall in East Africa and the Southern Oscillation. Journal of Climatology, 8(1), 31-43.

Okonkwo, C., \& Demoz, B. (2014). The relationship between El Niño Southern Oscillations and cereal $\begin{array}{lllll}\text { production in } \quad \text { Sahel. Environmental Hazards, } & \text { 13(4), 357. }\end{array}$ https://doi.org/10.1080/17477891.2014.940826

Parikh, J., \& Denton, F. (2002). Gender and climate change: Vulnerability, adaptation, mitigation and financial mechanisms. Proceedings and Thematic Paper prepared for COP8.

Parker, D. (1983). Documentation of a southern oscillation index. Meteorological Magazine, 12, 184-188.

Parry, M. L. (Ed.). (2007). Climate change 2007-impacts, adaptation and vulnerability: Working group II contribution to the fourth assessment report of the IPCC (Vol. 4). Cambridge University Press.

Pedercini, M., Kanamaru, H., \& Derwisch, S. (2012). Potential impacts of climate change on food security in Mali. Natural Resources Management and Environment Department, FAO, Rome. SCN 2010.

Pfaff, A., Broad, K., (1999). Glantz M.G. Who benefits from climate forecasts? Nature, 397, 645-646.

Rasmusson, E. M., \& Carpenter, T. H. (1982). Variations in tropical sea surface temperature and surface wind fields associated with the Southern Oscillation/El Niño. Monthly Weather Review, 110(5), 354-384. https://doi.org/10.1175/1520-0493(1982)110\%3C0354:VITSST\%3E2.0.CO;2

Ropelewski, C. F., \& Halpert, M. S. (1987). Global and regional scale precipitation patterns associated with the El Niño/Southern Oscillation. Monthly Weather Review, 115(8), 1606-1626. 
https://doi.org/10.1175/1520-0493(1987)115\%3C1606:GARSPP\%3E2.0.CO;2

Rosenzweig, C., \& Parry, M. L. (1994). Potential impact of climate change on world food supply. Nature, 367, 6459, 133-138. Retrieved from https://www.popline.org/node/302693

Shoko, K., \& Shoko, N. (2014). Drought and el nino phases in Zimbabwe.

Shuai, J., Zhang, Z., Tao, F., \& Shi, P. (2016), How ENSO affects maize yields in China: understanding the impact mechanisms using a process-based crop model. Int. J. Climatol., 36, 424-438.

Smith, J. B., Schneider, S. H., Oppenheimer, M., Yohe, G. W., Hare, W., Mastrandrea, M. D., ... \& Füssel, H. M. (2009). Assessing dangerous climate change through an update of the Intergovernmental Panel on Climate Change (IPCC)"reasons for concern". Proceedings of the national Academy of Sciences, 106(11), 4133-4137.

Thompson, B., Cohen, M. J., \& Meerman, J. (2012). World food insecurity and malnutrition: scope, trends, causes and consequences. In The Impact of Climate Change and Bioenergy on Nutrition (pp. 21-41). Springer Netherlands. https://doi.org/10.1007/978-94-007-0110-6_3

Tilman, D., Balzer, C., Hill, J., \& Befort, B. L. (2011). Global food demand and the sustainable intensification of agriculture. Proceedings of the National Academy of Sciences, 108(50), 20260-20264.

Timmer, C. P. (2005). Food Security and Economic Growth: an Asian perspective. Asian-Pacific Economic Literature, 19, 1-17.

Timmer, C. P. (2010). Reflections on food crises past. Food policy, 35(1), 1-11. https://doi.org/10.1016/j.foodpol.2009.09.002

Tirado, M. C., \& Meerman, J. (2012). Climate Change and Food and Nutrition Security. In Thompson B., \& Cohen M. (Eds.), The Impact of Climate Change and Bioenergy on Nutrition. Springer, Dordrecht. https://doi.org/10.1007/978-94-007-0110-6_4

Unganai, L. S. (1996). Historic and future climatic change in Zimbabwe, Clim. Res., 6, 137-145. Retrieved from http://www.jstor.org/stable/24865080

Ward, P. R., Verity, F., Carter, P., Tsourtos, G., Coveney, J., \& Wong, K. C. (2013). Food stress in Adelaide: the relationship between low income and the affordability of healthy food. Journal of environmental and public health, 968078. http://dx.doi.org/10.1155/2013/968078

Yokoyama, S. (2002). ENSO Impacts on Food Crop Production and the Role of CGPRT Crops in Asia and the Pacific. Coping against El Nino for Stabilizing Rainfed Agriculture: Lessons from Asia and the Pacific, 79.

Zavala, C. A. S., \& Cota, D. B. L. (2003). Relationship between ENSO and winter-wheat yields in Sonora, Mexico. Geofisica Internacional, 42(3), 341-350. Retrieved from, http://www.redalyc.org/pdf/568/56842306.pdf

\section{Notes}

Note 1. Alamgir and Arora (1991) also identified the macro-economy as playing a major role in determining food security at all levels.

Note 2. The countries most successful at this task are in East and Southeast Asia, although the experience in South Asia has been instructive as well (Timmer 2000).

Note 3. El Nino has occurred frequently since first reported in 1541 and has frequently produced drought over wide spread areas, disease outbreaks and wildlife losses (Hidore, 2010). According to Hidore (2010) the greatest costs associated with El Nino are those related to agriculture.

Note 4. According to Kovats (1999) the two extremes of ENSO are El Nino (warm event) and La Nina (cold event). The term 'El Nino' is frequently used to describe all aspects of ENSO phenomenon. Global climate anomalies associated with La Nina are generally less profound and, in some areas, tend to be the opposite of those that are associated with El Nino.

\section{Copyrights}

Copyright for this article is retained by the author(s), with first publication rights granted to the journal.

This is an open-access article distributed under the terms and conditions of the Creative Commons Attribution license (http://creativecommons.org/licenses/by/4.0/). 